\title{
Introduction: Intellectual History in Imperial Practice
}

René Koekkoek, Anne-Isabelle Richard and Arthur Weststeijn

Where does the Dutch empire fit in global intellectual history? The last twenty years have seen a burgeoning international literature on empire. ${ }^{1}$ However, the Dutch empire, writ large, has not benefitted from a similar scholarly engagement. What is the role of longstanding ideas circulating both in historiography and public debate, such as that the Dutch did not 'do' empire, just commerce, or that they did not develop (grand) visions about their empire, in this neglect? This volume is a step to

R. Koekkoek ( $\square)$

Department of History and Art History, Utrecht University, Utrecht, The Netherlands e-mail: r.koekkoek@uu.nl

A.-I. Richard

Institute for History, Leiden University, Leiden, The Netherlands e-mail: a.i.richard@hum.leidenuniv.nl

A. Weststeijn

Department of Languages, Literature \& Communication, Utrecht University, Utrecht, The Netherlands

e-mail: a.v.weststeijn@uu.nl

(C) The Author(s) 2019

R. Koekkoek et al. (eds.), The Dutch Empire between Ideas and Practice, 1600-2000, Cambridge Imperial and Post-Colonial Studies Series, https://doi.org/10.1007/978-3-030-27516-7_1 
integrating perspectives on Dutch empire into a broader global examination of visions of empire. ${ }^{2}$ It does so, on the one hand, by examining the trope of Dutch exceptionalism over the long term and from multiple perspectives. On the other hand, it argues that the Dutch case is particularly suited to connect with (recent) historiography that argues that not just canonical texts and speech acts but also meaningful practices are sources for intellectual history. ${ }^{3}$ In order to understand visions of empire, we need to look beyond systemic thinkers and also examine how various actors, 'intermediate thinkers of empire', articulated their visions in practice. ${ }^{4}$ Drawing on the concepts of upward and downward hermeneutics, this entails examining the interactions between ideas and practice; how ideas formed and were formed by socio-cultural and political practice. ${ }^{5}$ An intellectual history thus informed by social and cultural history allows for uncovering visions of Dutch empire expressed by a range of Dutch and other actors as empire was being 'done'. ${ }^{6}$ Such a history of visions of empire sheds new light on (current) historiography and public debate, precisely because dominant notions within this historiography and debate are rooted in the intellectual history of Dutch imperial practice.

\section{Looking in the Mirror: The Dynamics of Dutch Imperial (Self-)Perception}

The starting point of this volume is to show the possibility and importance of tracing ideas of Dutch empire across time. While avoiding teleology, connecting visions of empire of the early modern period to the state-led imperialism and postcoloniality of the nineteenth-twenty-first centuries allows for analysing the deep roots of dominant tropes in public discourse about the Dutch colonial past. A notorious example of these longstanding ideas in contemporary debate involved the then Prime Minister of The Netherlands, Jan Peter Balkenende. In June 2006, he was questioned in the Dutch House of Representatives by opposition parties about the recent recovery of the Dutch economy. Somewhat agitated, Balkenende replied: 'I don't understand why you're so negative and unpleasant about it. Let's be happy together. Let's be optimistic! Let's say: The Netherlands can do it. The VOC mentality, going abroad, dynamics!' When an indignant murmur rose from the House, the Prime Minister added a somewhat desperate '...right (toch)?' 
Balkenende's reference to the Dutch East India Company (VOC) generated a storm of protest in the following days and weeks. Under pressure of public opinion, Balkenende clarified that he did not want to gloss over the mistakes of the VOC past. He had meant the spirit of commerce and the courage to cross the oceans, not 'the dark age of slavery'. It did not satisfy Dutch-Surinamese action groups who promptly organized a demonstration and demanded apologies from the Prime Minister for his words. The activists sought to underline the interconnectedness of the Dutch role in the history of slavery and a broader underlying colonial mentality. It was a revealing episode in an ongoing series of debates on the Dutch imperial past, in which histories of the VOC merge with discussions about the Indonesian War of Independence, the Black Pete tradition and everyday racism. ${ }^{7}$ In these debates there are those who wish to defend and highlight a positive image of Dutch colonial history and seek to separate the 'golden days' from the 'dark pages'. Others argue that these aspects are necessarily entwined. Much like in other former imperial powers, the Dutch imperial past has become a site of contestation where conflicting visions of historical and cultural identity-formation clash.

In order to understand and contribute to these debates, it is important to situate the various visions of empire they draw upon. Invocations of an alleged great commercial imperial past or a Dutch exceptionalism have a long pedigree (and are not unlike claims about other empires). Particularly at moments of 'national' upheaval or reconstitution, the Dutch empire has been presented as a positive, benign phenomenon, for example in 1941, when Willem van Helsdingen, a retired high colonial official, published the book Daar werd wat groots verricht ('Great things were achieved there'). While the Netherlands had recently fallen to German occupation, this book was advertised as providing a compelling argument for the continuation of Dutch colonial rule overseas: 'We have developed the Indies as no other country in the world; we have brought peace and prosperity'. 8

Such visions of a civilizing mission did not go unchallenged. Already in 1913 for example, Soewardi Soerjaningrat, nationalist and later Indonesian Minister of Education, published the pamphlet Als ik eens Nederlander was, ... ('If I were a Dutchman, ...') in response to plans to celebrate the centenary of Dutch independence from Napoleonic France. In it he stated that 'If I were a Dutchman, I would never want to celebrate this centenary in a country that is occupied by us. First give them 
their freedom, then commemorate ours'. ${ }^{9}$ Soerjaningrat thus exposed the double standard that many visions of empire entail(ed). For this exposure he was ridiculed and banned from his home country. ${ }^{10}$

About a century earlier, when the Netherlands had just regained the independence they hoped to commemorate in 1913, an illustrious 'Dutch' commercial spirit rooted in the VOC was explicitly invoked in the two-volume Nederlandsche bezittingen in Azia, Amerika en Afrika ('Dutch possessions in Asia, America, and Africa'). Published in 1818 and written by the Dutch high military officer and future governor-general of the Dutch East-Indies, Johannes van den Bosch, this work offered the new Dutch state a comprehensive review of its imperial possessions - and suggestions how to increase their profitability. In his dedication to King William I, Van den Bosch stated that his work was informed by his wish to 'restore our weighty possessions overseas and advance the colonial trade to its highest possible prosperity, to restore the good old days of our forefathers and return our fatherland its glory and wealth'. ${ }^{11}$

The good old days Van den Bosch had in mind were those of the mid-seventeenth-century, the alleged 'Golden Age' of Dutch mercantile primacy worldwide. The celebration of Dutch colonial glory and wealth originated in the imperial visions created when the Dutch Republic challenged Spanish and Portuguese global supremacy. In the late 1630s, the apex of early modern Dutch expansion in Asia and the Atlantic, Joost van den Vondel, the Dutch 'prince of poets', dedicated a poem to the Amsterdam headquarters of the VOC in which he praised its global commercial enterprise: 'Wherever profit takes us, to every sea and shore, for love of gain the wide world's harbours we explore.' ${ }^{12}$ There is no hint in Vondel's poem of the Dutch involvement in the Atlantic slave trade, which took off exactly when he wrote these lines. The optimistic notion of a dynamic 'VOC-mentality' has long roots indeed.

These visions of a distinctly commercial Dutch empire were not only formulated in a Dutch context but also by other European observers. For example, in what has been called the 'first antislavery play', Oroonoko, the Royal Slave (1688), the British playwright Aphra Behn negatively compares the supposedly efficient, commercial and immoral Dutch to the - in her narrative-not too competent British. The assumption that the Dutch have a specific commercial mindset, allegedly different from that of other imperial powers, is a trope shared by Dutch and non-Dutch actors alike. 
These brief insights into the deep and widespread roots of Balkenende's notion of a 'VOC-mentality' show the relevance of holding up a mirror to the Dutch colonial past from a long term and transnational/transimperial perspective. Taking its clue from the coat of arms of the VOC, painted in 1651 and displayed on the cover, this volume seeks, firstly, to analyse the Dutch imperial (self-)perception of exceptionality: which image did the VOC present and evoke when it saw itself in the imperial mirror and how has that image influenced the way later (self-) perceptions are styled?

Arguably the most dominant trope in the representations of the Dutch empire is the idea that this empire was somehow 'exceptional' and 'different' from other empires. Most obviously, this discourse of exceptionalism can be observed in the recurring claim that the Dutch empire was essentially a maritime 'trading empire' rather than an example of expansionist imperialism - a claim also made manifest in the 1651 arms of the VOC, which show a merchant ship sailing between Neptune and a mermaid. The first part of this volume explores the origins and development of this rhetoric. Catia Antunes demonstrates why this 'spin' was useful in the contest of the Dutch Republic with the Portuguese and Spanish empires in the seventeenth century, and Arthur Weststeijn and Benjamin Schmidt show how it became a dominant vision of empire in the European Enlightenment. In essence, this early-modern narrative is still at play in contemporary historiography and public debate as Jennifer Foray argues. The prism of intellectual history allows us to uncover the long-term roots of this exceptionalist discourse and to explain why it is increasingly being challenged in recent scholarship. ${ }^{13}$

\section{Visions of Dutch Empire in Practice}

The second aim of the volume is combining more traditional intellectual history methodologies with an examination of the ways in which visions of empire have been developed in concrete imperial practice. This approach connects to the historiographical debate on (global) intellectual history where scholars such as Christopher Bayly have called to look beyond those that produced canonical ideological statements and for the importance of examining intellectual history through meaningful practices. As such it builds upon the notions of upward and downward hermeneutics that acknowledge the constitutive interaction between concepts and practice. ${ }^{14}$ 
As Alicia Schrikker refers to in her chapter, historians have long cherished the claim that the Dutch did not develop visions of empire: 'they just counted'. ${ }^{15}$ Arguably, this idea of 'just counting' makes the Dutch empire a privileged site to broaden our methodological toolbox. The way agents of empire 'counted' and expressed why they did so can provide insights into their visions of empire. This approach implies analysing the various 'media' of imperial (self-)perception, negotiation and control, including media in the sense of speech acts such as texts and broadcasts, but also for example urban architecture, visual imagery and meaningful practices such as courtroom procedures and colonial bureaucracy. ${ }^{16}$

Besides broadening the source material, this approach also entails broadening the subjects of analysis. It therefore opens up space to analyse the ideas of different types of agents of empire, both intellectuals and systemic thinkers as well as 'intermediate thinkers of empire' as Sanne Ravensbergen shows. The second part of the volume accordingly zooms in on numerous case studies of, among others, colonial officials, army officers, politicians and broadcasters who, interacting with agents from across the globe, articulated and negotiated specific visions of empire. Exploring a variety of practical contexts such as colonial governance, parliamentary debate, legal practices and radio broadcasting, the volume considers intellectual history in imperial practice broadly, aiming to reach a thorough understanding of the links between visions and practices of empire. Such an inclusive selection of sources and contexts, we argue, not only sheds new light on the intellectual history of the Dutch empire, but also explores new ways of writing the intellectual history of empire in general. ${ }^{17}$

Furthermore, by examining intellectual history in practice, in employing an upward hermeneutic, this volume shows how the predominantly 'Dutch' visions analysed in most chapters were in fact the result of dayto-day negotiations and interactions with other agents of empire from across the globe. The specific focus of this volume on the Dutch empire therefore should not be seen as a restatement of the long-dominant trope of Dutch 'exceptionalism', or as referring to a circumscribed set of actors, but rather as an invitation to look for entanglements between different national and imperial contexts through the prism of the Dutch empire.

These linkages operate through space, in a European imperial framework, between East and West, between Dutch imperialism in Asia and in the Atlantic and Caribbean. They also run through time: as the example 
of Balkenende's 'VOC-mentality' already indicates, the exploration of the history of imperial visions and (self-)perceptions requires a long-term perspective from the early modern period to the postcolonial age. As in the case of other empires, existing scholarship on the Dutch empire tends to be divided between early-modern and modern approaches, with a clear caesura generally being placed around 1800: the transitional period when the Dutch Republic ceased to exist and the Kingdom of the Netherlands came into being, while the Dutch empire changed from a Company-based imperial space to an imperial nation-state. ${ }^{18}$ Although these transitions may seem to justify a division between the early-modern and the modern period in terms of political, economic and social history, an intellectual history shows the fundamental continuities in the ways in which the Dutch empire was envisaged and remembered between the seventeenth and twenty-first centuries. ${ }^{19}$ An approach that argues for example to take the Congress of Vienna as a turning-point in Dutch and European imperial history, risks missing these continuities and therefore also misunderstanding the early-modern roots of contemporary imperial narratives.

Indeed, revealing and contextualizing the continuities and ruptures in the development of various concepts, ideas and visions of empire from the sixteenth century to the postcolonial era can suggest new ways to rethink the relationship between Dutch imperial history and its enduring impact on contemporary public culture and collective memory. While the traditional narrative held that there was no such thing as a Dutch empire, but only commercial enterprise rooted in an alleged VOC-mentality, approaches that seek to fragmentize Dutch imperial history into different temporal and spatial units risk bringing back that same old narrative. The concept of Dutch empire would then once again disappear out of sight, also in contemporary public debates. To counter that risk, this volume analyses the variety of features of Dutch imperialism since 1600 from a single comprehensive perspective, arguing that if we want to speak meaningfully about the Dutch empire today, we should analyse how historical actors thought, spoke and wrote about it in the past.

\section{Contents}

To place the traditional narrative of Dutch imperial exceptionalism in a critical historical perspective, the first part of this volume traces the roots of this narrative in the early-modern period and discusses its ongoing 
dominance in historical scholarship and public debate. In the first chapter, Catia Antunes explores the characteristics of the Dutch chartered colonial companies, the VOC and WIC, which have generally been seen as a unique feature of Dutch colonial enterprise and as the institutional foundation of the alleged commercial nature of Dutch imperialism. According to the existing historiography, the VOC and WIC were created mainly for economic reasons, and the resulting empire-building was only a contingent consequence of this economic rationale. However, as Antunes shows through a contextual analysis of the original charters of the VOC and WIC, this long-dominant view is mistaken. Co-opting the interests of the Dutch States-General and private entrepreneurs, the VOC and WIC were far from unique as means of organization for colonial exploitation. Indeed, they closely resembled comparable colonial mechanisms of the Spanish and Portuguese empires, and the Dutch colonial build-up in the seventeenth century was framed in similar terms to those of its Iberian predecessors. Moreover, the companies offered the States-General the opportunity to ascertain its domestic sovereignty and claim sovereignty overseas, in line with what Iberian sovereigns had been doing since the fifteenth century. The only truly exceptional feature of the early modern Dutch imperial enterprise, Antunes argues, was its openness to foreigners to participate in colonial expansion. This conclusion is especially important for our understanding of the national as well as international dimensions of the early-modern Dutch empire: while empire-building strengthened the sovereign claims of the 'national' state embodied by the States-General, it was also driven by non-Dutch agents.

The second chapter by Arthur Weststeijn continues to uncover the intellectual roots of the exceptionalist narrative of the Dutch empire as a trading empire. Starting from a Dutch colonial text written in Arabic, this chapter shows how this narrative originated in the humanist culture of the Dutch Republic in the pre-VOC years around 1600 and became ingrained in elite and popular culture in the following decades. While Dutch colonial rule overseas was clearly imperial in nature, its representation in the metropolis cherished the illusion of a non-imperial commercial enterprise that befitted the republican and corporate self-image of the Dutch Republic, especially of the city of Amsterdam. Analysing the ways in which this narrative surfaced in texts, imagery and urban architecture, including ephemeral triumphal arches and prominent buildings such as the Amsterdam Town Hall, Weststeijn argues that the idea of a non-territorial commercial empire gained weight because of its dominant 
manifestations in the Dutch public sphere around 1650. In the eighteenth century, when Dutch colonial expansion had come to a standstill, this idea was further elaborated in the visual culture of the European Enlightenment, especially in a series of frontispieces that celebrated Dutch commercial imperialism in the guise of a Company-Republic. As Weststeijn claims, the dominance of this representation of empire in terms of a corporate instead of a national entity, may explain why the concept of a 'Dutch empire' never materialized, unlike, for example, in early-modern Britain.

Benjamin Schmidt provides in Chapter 3 a further analysis of the ways in which prominent examples of Enlightenment culture effaced the Dutch role as a colonial actor by fashioning a European figure in its place. Schmidt calls this the hyper-imperial perspective, a vision of empire that, although created in Dutch print shops, promoted a distinctly continental vision of global expansion, replacing a territorial Dutch empire with a European empire of geography. While this chapter and Chapter 2 discuss the transnational context in which the Dutch empire developed, highlighting the similarities and differences between Dutch, Iberian and British imperial projects and visions, this chapter argues for analysing the intellectual history of the Dutch empire from a continental and global perspective, taking the example of the Dutch in Japan to show how Dutch imperial practice was turned into a pan-European vision by Dutch and non-Dutch actors alike, with Jonathan Swift's Gulliver's Travels as a case in point. Accordingly, a paradox can be discerned in the early-modern intellectual history of the Dutch empire: although the Dutch imperial project, as argued by Antunes, strengthened the claims for national sovereignty by the States-General, its representation in texts and images occluded this national dimension and highlighted either its local and corporate aspects, in Weststeijn's analysis, or, in Schmidt's words, its hyper-imperial character.

The long-term consequences of this early-modern narrative are discussed in Chapter 4 by Jennifer Foray. The chapter reflects on a number of recent historiographical interventions in the field of modern Dutch imperialism and decolonization as well as the challenges of studying these subjects. It argues that, at least in part, such challenges stem from persistent, even reflexive claims concerning the 'exceptional' nature of Dutch imperialism and decolonization. Rather than examining the historical origins, as the previous chapters have done, or the merits of these claims of Dutch exceptionalism, Foray explores how these claims 
of Dutch exceptionalism and uniqueness continue to shape academic and popular understandings of these subjects, as seen in recently published studies, museum exhibits, and public exchanges between scholars. Simple linguistic devices, such as the 'yes, but...' ('ja, maar...') phraseology, have been used to qualify the Netherlands as somehow different from other empires and therefore outside the realm of meaningful comparison. The chapter supports the creation of a comparative, far-reaching 'New Imperial History' undertaken by a global community - and perhaps a new generation - of scholars examining the history and legacies of the Dutch empire.

The chapters in the second part of this volume explore how visions of Dutch empire emerged out of and in interaction with imperial practices both overseas and in the metropole. Whereas superficially they may seem 'Dutch' visions, the focus on how they developed in practice shows that actors from across the globe, be they other colonial agents, transnational movements or local populations had a formative influence.

The chapter by Alicia Schrikker surveys the crucial period of the dismantling of the VOC and ensuing political bickering over the future of the Dutch empire in Asia. It argues that the VOC-and the later colonial archive-functioned as institutional memory that contained canonized knowledge and absorbed local experiences and mixed this with current political ideals. It is within this blend of practice, memory and ideas that we can locate fragmented yet lasting expressions of Dutch colonial ideology. Despite the constitutional and geographic transformation of the Dutch empire, the chapter argues that Dutch colonial culture in Asia did not transform radically, but rather gradually and that the visions and practices of the colonial state can only be understood in relation to its Company past, building upon the legacy of the VOC as a state-like creature, with territorial claims where authority was mediated and executed through Dutch-Indigenous institutions like landraden and other civil courts in rural Sri Lanka, the Cape, Ambon and Java's Northeast coast.

René Koekkoek builds on the chapter by Schrikker and examines the neglected era of the late eighteenth-century Batavian Revolution and the revolutionary debates in the metropole about the future political architecture of the Dutch empire. He argues that it was in the turbulent context of Atlantic imperial revolutions, uncertainty, international warfare, and the massive slave revolt on French Saint-Domingue, that Batavian revolutionaries transformed the company-ruled empire into a state-ruled colonial empire. Informed by ideals of the new nation-state's 'unity and 
indivisibility' but severely checked by an unpredictable geopolitical reality, Batavian revolutionaries had to negotiate their imperial ideas and ideals. The ideal of a constitutionally unified empire of equal citizens was qualified from the beginning and soon abandoned. Yet Batavian revolutionaries laid the conceptual and constitutional foundations of the imperial sovereignty of a centralized Dutch state, although the immediate impact on actual colonial practices was initially limited.

The chapter by Sanne Ravensbergen offers a critical assessment of the vision of the rule of law as well as the actual practices of the liberal colonial jurists within the legal plural space of the landraden (colonial law courts) in nineteenth-century Java. Liberal Dutch lawyers and judges in Java, 'intermediate' thinkers of empire, depicted themselves as 'bearers of civilization', and subsequent historians have repeated this. The chapter asks what changed in the legal practice of the landraad after Dutch Liberals managed to introduce an independent president and what happened to the visions of the liberal jurists after they started practising them in the reality of the colonial courtroom. It shows that not only the Dutch president of the court, but also the Javanese court members and other local elites, 'practised' their visions. The visions and practices of all these actors interacting together formed and shaped a colonial legal culture in nineteenth-century Java. Although the visions of colonial jurists are often overlooked, as they were not the producers of high scholarship, they did contribute to an 'industry' of liberalism by expressing their views in societies, publishing pamphlets, writing in liberal magazines, and arguing in Dutch parliament. By taking the developing visions of the practicing colonial jurists seriously, it becomes possible to connect imperial visions to jurispractice.

In his chapter, Vincent Kuitenbrouwer explores visions of empire in the practice of radio broadcasting in the Netherlands Indies of the 1920s and 1930s. He argues that the early history of radio broadcasting in the Netherlands Indies throws a revealing light on the 'blind spots' of the late Dutch colonial state. More in particular, Kuitenbrouwer maintains that the original motivations behind the Dutch-Indies Radio Broadcasting Company - to create more imperial unity and strengthen 'Dutch elements' in the colony-paved the way for two developments. First, the broadcasting company started to function as an (informal) 'arm' of the Dutch colonial authorities as it assumed the responsibility of upholding social order and monitoring public opinion. Second, the distinction made by the broadcasting company's Advisory Board between 
'Western' and 'Eastern' listeners was in reality much more diffuse. The 'imperial' ether thus offered the opportunity to broadcast 'subversive' music-Krontjong - that was embraced by the Indonesian anti-colonial nationalist movement.

The chapters by Koekkoek, Schrikker, Ravensbergen and Kuitenbrouwer demonstrate how visions of empire were forged in the confrontation with practical realities. Clearly, ideas shaped practices. But practices shaped ideas too. Such practices could be both external and part of larger transnational and imperial contexts, such as in the revolutionary 1790s, and internal, such as in the long-term institutional memory of the VOC past. Moreover, 'practiced visions', for example, of Dutch lawyers in the 1840-1880s could underpin colonial rule and a colonial legal culture. But as Kuitenbrouwer shows, the confrontation of imperial visions by Dutch broadcasters with the actual practice could also lead to unexpected and unintended outcomes that undermined Dutch colonial rule.

Finally, in his epilogue Remco Raben offers a wide-ranging, longue durée interpretation of the historical development of visions of Dutch empire. First, he explores a recurring series of tensions, if not outright contradictions, between metropolitan visions of empire 'at home' and imperial praxis abroad. In part, these tensions could exist and continue to exist, Raben explains, by the skewing, selecting, filtering and muting of information about the colonial empire that was made available for 'home consumption'. Second, he points to the notion of 'distance'geographical, mental as well as intellectual-as a structuring condition for the emergence of imperial visions. Empire, in short, happened 'elsewhere' and this allowed a vision of exceptionalism to develop. Lastly, Raben argues that although the voices of 'the colonized' have been muted, neglected and repressed throughout Dutch colonial and postcolonial history - they have always been there.

This volume, then, does not pretend to offer the last word on the subject but rather aims to open up a field of research that needs to be explored in more detail. It argues that an intellectual history of empire benefits from a source base that includes meaningful practices and takes intermediate thinkers seriously, embedded in long term, transnational and transimperial perspectives. We hope the various essays in this volume can serve as an invitation for more comprehensive and integrated studies that will bring to the fore the variety of voices involved in the intellectual history of imperial practice. 


\section{Notes}

1. See Samuel Moyn and Andrew Sartori, ed., Global Intellectual History (New York: Columbia University Press, 2013). See also e.g. David Armitage, The Ideological Origins of the British Empire (Cambridge: Cambridge University Press, 2000); Antony Anghie, Imperialism, Sovereignty and the Making of International Law (Cambridge: Cambridge University Press, 2004); Jennifer Pitts, A Turn to Empire: The Rise of Imperial Liberalism in Britain and France (Princeton: Princeton University Press, 2005); Gabriel Paquette, Enlightenment, Governance, and Reform in Spain and Its Empire 1759-1808 (Basingstoke: Palgrave Macmillan, 2008); Duncan Kelly, ed., Lineages of Empire: The Historical Roots of British Imperial Thought (Oxford: Oxford University Press, 2009); Lauren Benton, A Search for Sovereignty: Law and Geography in European Empires, 1400-1900 (Cambridge: Cambridge University Press, 2010); Sankar Muthu, ed., Empire and Political Thought (Cambridge: Cambridge University Press, 2014); Andrew Fitzmaurice, Sovereignty, Property and Empire, 1500-2000 (Cambridge: Cambridge University Press, 2014); Anthony Pagden, The Burdens of Empire: 1539 to the Present (Cambridge: Cambridge University Press, 2015); and Duncan Bell, Reordering the World: Essays on Liberalism and Empire (Princeton: Princeton University Press, 2016).

2. The volume results from a conference at Leiden University and accompanying discussion forum that critically explored this discrepancy in the existing scholarship on Dutch colonial history: René Koekkoek, AnneIsabelle Richard, and Arthur Weststeijn, 'Visions of Dutch Empire: Towards a Long-Term Global Perspective,' BMGN-Low Countries Historical Review 132, no. 2 (2017): 79-96; Andrew Fitzmaurice, 'The Dutch Empire in Intellectual History,' Ibidem: 97-109; and Susan Legêne, 'The European Character of the Intellectual History of Dutch Empire,' Ibidem: 110-120. These three (open access) articles provide a wide-ranging discussion of the existing historiography on the intellectual history of empire and on the Dutch empire in general.

3. C.A. Bayly, 'The Ends of Liberalism and the Political Thought of Nehru's India,' Modern Intellectual History 12 (2015): 605-626, 613.

4. Emma Rothschild. 'Language and Empire, c.1800,' Historical Research 78 (2005): 223-226; Emma Rothschild, The Inner Lives of Empire: An Eighteenth-Century History (Princeton: Princeton University Press, 2011).

5. For upward and downward hermeneutics see David Armitage, Foundations of Modern International Thought (Cambridge: Cambridge University Press, 2012), 8; C.A. Bayly, Recovering Liberties: Indian Thought in the Age of Liberalism and Empire (Cambridge: Cambridge 
University Press, 2011), 343; and Anthony Giddens, Social Theory and Modern Sociology (Cambridge: Cambridge University Press, 1987).

6. Glenda Sluga and Timothy Rose, 'Introduction,' Modern Intellectual History 12, no. 3 (2015): 523-528, 528.

7. The contributions to these debates are too numerous to list. For a recent intervention that also gives an overview of the development of these debates over the last decades see Larissa Schulte Nordholt and Remco Raben, 'Het postkoloniale debat is vooral politiek. "Principes? Niet overzee",' De Groene Amsterdammer 143, no. 6 (February 2019). For the term everyday racism see Philomena Essed, Understanding Everyday Racism: An Interdisciplinary Theory (Newbury Park, CA: Sage, 1991), 52.

8. As cited in: C. Fasseur, 'Nederland en het Indonesische nationalisme. De balans nog eens opgemaakt,' BMGN 99 (1988): 21-45, 21.

9. R.M. Soewardi Soerjaningrat, Als ik eens een Nederlander was, ... (Bandung, 1913), 16.

10. E.F.E. Douwes Dekker, Onze Verbanning (Schiedam, 1913).

11. Johannes van den Bosch, Nederlandsche bezittingen in Azia, Amerika en Afrika. In derzelver toestand en aangelegenheid voor dit Rijk, wijsgeerig, staatshuishoudkundig en geographisch beschouwd, 2 vols. (The Hague: Van Cleef, 1818), $\mathrm{x}$.

12. Joost van den Vondel, 'Op het OostIndischhuis,' in Blyde inkomst der allerdoorluchtighste koninginne, Maria de Medicis, t'Amsterdam (Amsterdam, 1639), 40: 'Al waer de winst ons voert, na alle zeen en kusten. Gewinzucht liet tot noch geen havens onbezocht.' Translation taken from C.R. Boxer, The Dutch Seaborne Empire, 1600-1800 (London: Hutchinson, 1977), 28.

13. For recent scholarship see for example: Remco Raben, 'A New Dutch Imperial History: Perambulations in a Prospective Field,' BMGN-Low Countries Historical Review 128, no. 1 (2013): 5-30; Elizabeth Buettner, Europe After Empire: Decolonization, Society, and Culture (Cambridge: Cambridge University Press, 2016); and Gloria Wekker, White Innocence: Paradoxes of Colonialism and Race (Durham: Duke University Press, 2016).

14. See esp. the literature in note 5 .

15. See also Martine van Ittersum and Jaap Jacobs, 'Are We All Global Historians Now? An Interview with David Armitage,' Itinerario 36, no. 2 (2012): 7-28.

16. Cf. Bayly, 'The Ends of Liberalism and the Political Thought of Nehru's India.'

17. In this we follow the approach suggested by Andrew Fitzmaurice in 'The Dutch Empire in Intellectual History.' 
18. For imperial nation state see Gary Wilder, The French Imperial Nation State: Negritude and Colonial Humanism Between the Two World Wars (Chicago: University of Chicago Press, 2005).

19. A possible Dutch imperial meridian: cf. C.A. Bayly, Imperial Meridian: The British Empire and the World, 1780-1830 (Harlow: Routledge, 1989); David Todd, 'A French Imperial Meridian, 1814-1870,' Past and Present 210, no. 1 (2011): 155-186.

Open Access This chapter is licensed under the terms of the Creative Commons Attribution 4.0 International License (http://creativecommons.org/licenses/ by $/ 4.0 /$ ), which permits use, sharing, adaptation, distribution and reproduction in any medium or format, as long as you give appropriate credit to the original author(s) and the source, provide a link to the Creative Commons license and indicate if changes were made.

The images or other third party material in this chapter are included in the chapter's Creative Commons license, unless indicated otherwise in a credit line to the material. If material is not included in the chapter's Creative Commons license and your intended use is not permitted by statutory regulation or exceeds the permitted use, you will need to obtain permission directly from the copyright holder.

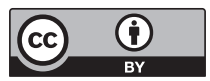

